Kummer, J. A., C. J. Nordell, T. M. Berry, C. V. Collins, C. R. L. Tse, and E. M. Bayne. 2016. Use of bird carcass removals by urban scavengers to adjust bird-window collision estimates. Avian Conservation and Ecology 11(2):12. http://dx.doi.org/10.5751/ACE-00927-110212

Copyright (C) 2016 by the author(s). Published here under license by the Resilience Alliance.

Research Paper

\title{
Use of bird carcass removals by urban scavengers to adjust bird- window collision estimates
}

\author{
Justine A. Kummer ${ }^{1}$, Cameron J. Nordell ${ }^{1}$, Taylor M. Berry ${ }^{1}$, Colina V. Collins ${ }^{1}$, Casandra R.L. Tse ${ }^{1}$ and Erin M. Bayne \\ ${ }^{1}$ Department of Biological Sciences, University of Alberta
}

\begin{abstract}
Carcass removal by scavengers has been identified as one of the largest biases in estimating bird mortality from anthropogenic sources. Only two studies have examined carcass removal by scavengers in an urban environment, and previous estimates of bird-window collision mortality at houses have relied on carcass removal rates from wind turbine studies. We placed a bird carcass and time-lapse camera at 44 houses in Edmonton, Alberta. In total, 166 7-day trials were conducted throughout 2015. Time-to-event (survival) analysis was used to identify covariates that affected removal. The carcass removal rate was determined for use in estimating the number of birds killed from bird-window collisions at houses in Alberta. In total, $67.5 \%$ of carcasses were removed. The date the carcass was placed, the year the house was built, and the level of development within $50 \mathrm{~m}$ of the house were the covariates that had the largest effect on carcass removal. In calculating our removal rate, the number of detected carcasses in the first 24 hours was adjusted by 1.47 to account for removal by scavengers. Previously collected citizen science data were used to create an estimate of 957,440 bird deaths each year in Alberta as a result of bird-window collisions with houses. This number is based on the most detailed bird-window collision study at houses to date and a carcass removal study conducted in the same area. Similar localized studies across Canada will need to be completed to reduce the biases that exist with the previous bird-window collision mortality estimate for houses in Canada.
\end{abstract}

\section{Incorporation du prélèvement de carcasses d'oiseaux par les charognards urbains dans l'estimation du taux de collision des oiseaux avec les fenêtres}

RÉSUMÉ. Le prélèvement de carcasses par les charognards a été identifié comme un des biais les plus importants dans l'estimation de la mortalité d'oiseaux attribuable à des causes d'origine humaine. Seules deux études ont examiné le prélèvement de carcasses par les charognards en milieu urbain, et les estimations précédentes de la mortalité d'oiseaux par collision avec les fenêtres de maisons ont utilisé des taux de prélèvement de carcasses provenant d'études réalisées pour les éoliennes. Nous avons déposé des carcasses d'oiseaux et positionné des caméras à prises de vues par intervalle à 44 maisons à Edmonton, Alberta. En tout, 166 essais de 7 jours ont été effectués en 2015. Une analyse du temps d'apparition de l'événement (survie) a été faite pour déterminer les covariables qui agissent dans le prélèvement de carcasses. Le taux de prélèvement de carcasses a été établi afin d'être subséquemment utilisé dans l'estimation du nombre d'oiseaux morts par collision avec les fenêtres de maisons en Alberta. Nous avons estimé ce taux à 67,5\% . La date de dépôt de la carcasse, l'année de construction de la maison et le degré d'urbanisation dans un rayon de $50 \mathrm{~m}$ de la maison étaient les covariables qui avaient le plus d'effets sur le prélèvement de carcasses. Dans notre calcul du taux de prélèvement, le nombre de carcasses détectées dans le premier 24 h a été multiplié par 1,47 pour tenir compte de leur prélèvement par les charognards. Des données précédemment colligées et provenant de programmes auxquels contribuent les citoyens ont été utilisées pour estimer la mortalité d'oiseaux par collision avec les fenêtres de maisons à 957440 chaque année, en Alberta. Cette estimation est fondée sur l'étude la plus détaillée sur les collisions d'oiseaux avec les fenêtres de maisons à ce jour et sur une étude de prélèvement de carcasses effectuée dans le même secteur. Des études locales similaires devront être effectuées ailleurs au Canada afin de réduire les biais existants dans l'estimation antérieure de la mortalité d'oiseaux par collision avec les fenêtres de maisons au Canada.

Key Words: bird mortality; bird-window collisions; carcass removal; scavenger removal; urban scavengers

\section{INTRODUCTION}

Increasing urbanization creates a number of human-related threats to birds, including collisions with windows, automobile strikes, and predation by cats (Calvert et al. 2013, Machtans et al. 2013, Loss et al. 2014). In a recent review of anthropogenic factors that kill birds directly, collisions with windows and predation by cats were identified as the two largest sources of avian mortality in Canada (Calvert et al. 2013). However, in that series of papers there were numerous caveats related to the accuracy of the various mortality estimates. Many reviews identify the removal of carcasses before an observer has a chance to detect them as one of the largest biases in estimating bird mortality from anthropogenic sources (Smallwood et al. 2010, Hager et al. 2012).

Previous studies of bird-window collisions have tended to use the presence of a dead bird as evidence of a bird-window

Address of Correspondent: Justine A Kummer, Department of Biological Sciences, University of Alberta, CW 405 Biological Sciences Building, Edmonton, AB, CA, T6G 2E9, E-mail: kummer@ualberta.ca, Phone: 1-780-492-6873, kummer@ualberta.ca

Erratum: This paper was originally published with incorrect captions and figures. The error was corrected on 16 December 2016. 
collision. However, a large number of collisions are occurring that do not result in a carcass being located (Bayne et al. 2012). In determining the most recent bird-window collision estimate for houses, Machtans et al. (2013) accounted for missed mortalities using data from Zimmerling et al. (2013) and Dunn (1993). The lower estimate came from Zimmerling et al. (2013), who determined the combined effect of losses from scavengers and searcher error based on 36 post-construction monitoring studies of wind turbines. With $62.4 \%$ of birds not scavenged and $69.0 \%$ of birds found, it was estimated that 2.3 birds were missed for each bird found. The upper estimate came from Dunn (1993), who, in her study that focused on winter bird mortality from collisions with windows, speculated that up to five birds may die for every bird that is found.

To date, estimates of carcass removal rates by scavengers and the bias created in estimates of avian mortality rates from human activities have been estimated primarily at wind farms, at power lines, and in pastures (Balcomb 1986, Tobin and Dolbeer 1990, Wobeser and Wobeser 1992, Ragg et al. 2000, Kostecke et al. 2001, Smallwood 2007, Prosser et al. 2008, Ponce et al. 2010, Smallwood et al. 2010, Villegas-Patraca et al. 2012, Bispo et al. 2013, Smallwood 2013). Two studies have estimated carcass removal by scavengers in an urban landscape (Table 1). Bracey et al. (2016) conducted their study at 42 houses along Lake Superior in Minnesota, USA. Scavenging rates increased with distance from the city center and decreased as length of time the carcass was available on the landscape increased. However, this study focused only on carcasses removed during bird migration. Hager et al. (2012) documented scavenger activity at 20 buildings in Rock Island and Moline, Illinois by considering the local habitat covariates that influence carcass removal at buildings of various sizes in an urban landscape. Carcass removal was negatively correlated with canopy cover and window area, and was positively correlated with pavement cover. This study considered seasonality and found that the daily chance of a carcass remaining was greater in winter than during the other seasons. Whether similar patterns and rates occur in areas of North America that have different seasonal patterns and scavenger communities remains unclear and should be explored to develop accurate mortality estimates for birds in urban areas.

Our first objective was to understand the role scavengers play in urban ecology and identify the covariates that affect the removal of carcasses. The second objective was to create a correction factor for carcass removal by scavengers when estimating bird-window collision mortality, and apply it to a yearly bird-window collision mortality estimate for houses in Alberta, Canada by using citizen science data that are specific to this region (Kummer et al. 2016a).

\section{METHODS}

\section{Site selection}

Houses for this experiment were identified by using a variety of methods. Homeowners in the Edmonton, Alberta area who had previously registered for our Birds and Windows Project (http:// birdswindows.biology.ualberta.ca/) were contacted and asked to participate in the study. Homeowners were also recruited through personal contact and social media (Facebook and Twitter accounts). In total, 44 houses within Edmonton and the surrounding area were used.

\section{Experimental design}

The study was conducted from January to November 2015, although no trials were completed in April or September. At each house, one to six trials were completed over the study period. Each trial spanned 7 days, with setup on the first day and takedown on the seventh. The timing of each trial throughout the study period was randomized based on homeowner approval.

During setup, a bird carcass was placed on its back in front of the largest window on the front yard of each home. While there may be important differences in scavenger abundance and carcass detection between front yards and backyards, we chose to exclude this potential source of variation in our study. The carcasses used were obtained from the Royal Alberta Museum in Edmonton, a large number of which were provided by homeowners after a birdwindow collision. Carcasses were of various sizes $(5-27 \mathrm{~cm})$ and species. All carcasses were provided to us frozen, and remained in this state until they were thawed and placed at the residences. The carcasses were kept in plastic bags until they were placed at the houses to reduce human contact and contamination.

Brinno $^{\mathrm{TM}}$ Time Lapse Cameras (TLC200) were used to capture removal events. The cameras were placed on the ground facing the carcass, with an average distance of $30 \mathrm{~cm}$ separating the lens from the carcass. The lens was adjusted to center the carcass in the camera frame. Cameras were programmed for time-lapse to capture one frame per second, and the time and date were programmed during setup.

On the seventh day, the houses were revisited to remove the camera and the remainder of the carcass, if necessary. A scavenging event was defined as the removal of the carcass from its original location or the consumption of a carcass by a scavenger at its original location. If the carcass was visited and disturbed by a scavenger but not removed or consumed, it was not defined as a scavenging event. Instances where only feathers remained were considered scavenging events. Photos from each camera were used to determine the type of scavenger, as well as the time and date of each carcass removal, if possible.

\section{Data collection}

During each setup, we recorded (1) the date the carcass was placed below the window (hereafter DATE), (2) the time the carcass was placed below the window (TIME), and (3) the distance the bird carcass was placed from the window (WINDOWDIST). At each house, the bird was placed $1 \mathrm{~m}$ from the window. If the bird could not be placed at this distance, it was placed closer or further from the window, depending on which distance was closer to the originally intended $1 \mathrm{~m}$. This resulted in an average distance of $96.20 \mathrm{~cm}$. If the $1 \mathrm{~m}$ distance was under trees or shrubs, the carcass was placed there if possible.

The first time we visited each house, we recorded (1) the density of vegetation in a $2 \mathrm{~m}$ area surrounding the placed carcass (dense or sparse) (WINDOWDENS), and (2) the type of ground cover on which the carcass was placed (grass, dirt, and mulch/rock) (GRNDCOVER). If a carcass was placed under a tree or shrub, GRNDCOVER was identified as the surface the carcass was laying on underneath the vegetation.

Information on each house was collected during setup and from the City of Edmonton, City of St. Albert, and Sherwood Park 
Table 1. Summary of studies that focused on the removal of carcasses by scavengers.

\begin{tabular}{|c|c|c|c|c|}
\hline$\underline{\text { Study }}$ & Location & Human activity & Experiment & Results \\
\hline Balcomb (1986) & Beltsville, Md. & Agriculture field & $\begin{array}{l}78 \text { carcasses were placed in corn fields } 0- \\
7 \text { days after planting for } 5 \text { days }\end{array}$ & $\begin{array}{l}\text { Average survival time was } 1.6(\mathrm{SD}= \\
1.9,1981) \text { and } 0.9(\mathrm{SD}=1.1,1982) \\
\text { days }\end{array}$ \\
\hline Bispo et al.(2013) & Portugal & Wind farms & $\begin{array}{l}\text { Carcasses were placed under } 10 \text { wind } \\
\text { turbines for } 7 \text { days }\end{array}$ & $\begin{array}{l}\text { Average percent of carcasses } \\
\text { remaining ranged from } 22 \text { to } 58 \%\end{array}$ \\
\hline Bracey et al.(2016) & Duluth, Minn. & Houses & $\begin{array}{l}140 \text { carcasses were placed at } 42 \text { houses } \\
\text { for } 6 \text { days }\end{array}$ & $\begin{array}{l}\text { Estimated survival time was } 4.33+/- \\
0.14 \text { days }\end{array}$ \\
\hline Erikson et al.(2000) & Pendleton, Oreg. & Wind farm & $\begin{array}{l}80 \text { carcasses were placed under wind } \\
\text { turbines for } 28 \text { days }\end{array}$ & Average survival time was 25.0 days \\
\hline Hager et al.(2012) & $\begin{array}{l}\text { Rock Island and } \\
\text { Moline, Ill. }\end{array}$ & $\begin{array}{l}\text { Urban buildings } \\
\text { of various size }\end{array}$ & $\begin{array}{l}80 \text { carcasses were placed at } 20 \text { buildings } \\
\text { for } 7 \text { days }\end{array}$ & $\begin{array}{l}\text { Estimated mean carcass survival times } \\
\text { ranged from } 22.7 \text { to } 212.0 \text { days in } \\
\text { winter and } 3.5 \text { to } 29.6 \text { days in other } \\
\text { seasons }\end{array}$ \\
\hline $\begin{array}{l}\text { Horn and Collins } \\
(2006)\end{array}$ & Decatur, Ill. & $\begin{array}{l}\text { University } \\
\text { buildings }\end{array}$ & $\begin{array}{l}\text { Chicken breasts were placed at five } \\
\text { locations over } 40 \text { days }\end{array}$ & $\begin{array}{l}\text { Average scavenging rate was } 2.4-2.6 \\
\text { days }\end{array}$ \\
\hline Klem et al. (2004) & Allentown, $\mathrm{Pa}$. & $\begin{array}{l}\text { University } \\
\text { buildings }\end{array}$ & $\begin{array}{l}539 \text { chicken breasts were placed at six } \\
\text { locations over } 77 \text { days }\end{array}$ & $\begin{array}{l}12.8 \% \text { of carcasses were found and } \\
\text { disturbed }\end{array}$ \\
\hline Kostecke et al.(2001) & $\begin{array}{l}\text { Alrington and Ramona, } \\
\text { S. Dak. }\end{array}$ & $\begin{array}{l}\text { Grassland, crop } \\
\text { fields, roadside, } \\
\text { and wooded } \\
\text { habitat }\end{array}$ & $\begin{array}{l}454 \text { carcasses were placed at } 46 \text { transects } \\
\text { for } 5 \text { days }\end{array}$ & $66 \%$ of carcasses were scavenged \\
\hline Pain (1991) & France & Marsh land & $\begin{array}{l}60 \text { carcasses were placed in three } \\
\text { landscape types }\end{array}$ & $\begin{array}{l}\text { Average survival time was } 1.5 \text { days on } \\
\text { land, } 3.3 \text { days in vegetation, and } 7.6 \\
\text { days exposed on water }\end{array}$ \\
\hline Ponce et al.(2010) & Spain & Power lines & $\begin{array}{l}522 \text { carcasses were placed under power } \\
\text { lines for } 5 \text {-month trials }\end{array}$ & $\begin{array}{l}32 \% \text { of carcasses were scavenged after } \\
48 \text { hours }\end{array}$ \\
\hline Prosser et al.(2008) & England & Agriculture field & $\begin{array}{l}450 \text { were carcasses placed at } 57 \text { trial } \\
\text { plots for } 4-7 \text { days }\end{array}$ & $\begin{array}{l}6 \% \text { of carcasses were removed after } 24 \\
\text { hours in February and } 77 \% \text { were } \\
\text { removed in May }\end{array}$ \\
\hline Ragg et al.(2000) & New Zealand & Agriculture fields & $\begin{array}{l}10 \text { ferrets, } 12 \text { possums, } 2 \text { hedgehogs, and } \\
7 \text { rabbits were monitored on farmland } \\
\text { until totally scavenged }\end{array}$ & $\begin{array}{l}\text { Ferrets scavenged } 5 / 8 \text { ferret carcasses, } \\
8 / 9 \text { possum carcasses, and } 6 / 7 \text { rabbit } \\
\text { carcasses encountered }\end{array}$ \\
\hline $\begin{array}{l}\text { Rosene and Lay } \\
\text { (1963) }\end{array}$ & $\begin{array}{l}\text { Union Springs, Ala., } \\
\text { and Buna, Tex. }\end{array}$ & Agriculture fields & $\begin{array}{l}60 \text { carcasses were placed in fields for } 4 \\
\text { days }\end{array}$ & $\begin{array}{l}13 \% \text { were removed within } 24 \text { hours in } \\
\text { Alabama and } 7 \% \text { in Texas }\end{array}$ \\
\hline $\begin{array}{l}\text { Smallwood et al. } \\
\text { (2010) }\end{array}$ & $\begin{array}{l}\text { Byron Contra Costa } \\
\text { County, Calif. }\end{array}$ & Wind farm & $\begin{array}{l}64 \text { carcasses were placed at } 20 \text { wind } \\
\text { turbines for } 21 \text { days }\end{array}$ & $\begin{array}{l}\text { Average survival time was } 4.45 \text { days } \\
(\mathrm{SD}=5.69)\end{array}$ \\
\hline Stevens et al.(2011) & $\begin{array}{l}\text { Browns Bench and } \\
\text { Upper Snake, Idaho }\end{array}$ & Fences & $\begin{array}{l}100 \text { carcasses were monitored at two } \\
\text { study sites for } 31 \text { days }\end{array}$ & $\begin{array}{l}\text { Average carcass daily survival } \\
\text { probability ranged from } 0.776 \text { to } 0.812\end{array}$ \\
\hline $\begin{array}{l}\text { Tobin and Dolbeer } \\
\text { (1990) }\end{array}$ & $\begin{array}{l}\text { Columbia and Ulster } \\
\text { counties, N.Y. }\end{array}$ & Orchards & $\begin{array}{l}\text { Carcasses were placed under } 25 \text { trees in } \\
\text { eight orchards for } 11-12 \text { days }\end{array}$ & $\begin{array}{l}\text { Average survival time was } 8.2 \text { days (SE } \\
1.2 \mathrm{~d} \text { ) for cherry orchards and } 10.4 \\
\text { days }(\mathrm{SE}=1.4 \mathrm{~d} \text { ) for apple orchards }\end{array}$ \\
\hline $\begin{array}{l}\text { Villegas-Patraca et al. } \\
(2012)\end{array}$ & Mexico & Wind farm & $\begin{array}{l}120 \text { carcasses were placed under wind } \\
\text { turbines for } 20 \text { days }\end{array}$ & $\begin{array}{l}\text { Average time to removal was } 2.1-4.4 \\
\text { days in the dry season and } 2.7-4.4 \\
\text { days in the rainy season }\end{array}$ \\
\hline Ward et al.(2006) & $\begin{array}{l}\text { Athens-Clarke county, } \\
\text { Ga. }\end{array}$ & $\begin{array}{l}\text { Urban and rural } \\
\text { land }\end{array}$ & $\begin{array}{l}192 \text { carcasses were placed in rural and } \\
\text { urban land use areas for } 6 \text { days }\end{array}$ & $\begin{array}{l}\text { Average survival time was } 1.6 \text { days in } \\
\text { rural areas and } 2.1 \text { days in urban areas }\end{array}$ \\
\hline $\begin{array}{l}\text { Wobeser and Wobeser } \\
\text { (1992) }\end{array}$ & Saskatoon, Sask. & Pasture & $\begin{array}{l}250 \text { were carcasses placed in pasture for } \\
5 \text { days }\end{array}$ & $\begin{array}{l}80.4 \% \text { of carcasses were removed } \\
\text { within } 24 \text { hours }\end{array}$ \\
\hline Woronecki et al.(1979) & $\begin{array}{l}\text { Ottawa, Sandusky, and } \\
\text { Lucas counties, Ohio }\end{array}$ & Agriculture field & $\begin{array}{l}140 \text { carcasses were placed in } 12 \text { test fields } \\
\text { for } 8 \text { days }\end{array}$ & $\begin{array}{l}28 \% \text { of carcasses were removed within } \\
24 \text { hours }\end{array}$ \\
\hline
\end{tabular}

websites. This included (1) the year the house was built (YRBUILT), and (2) the direction the study window faced (WINDOWDIRECT). All selected houses were single-detached homes (Government of Canada 2011). Google Earth Pro was used to determine (1) the density of vegetation in the yard of the house the study window overlooked (dense or sparse) (YARDDENS), (2) the average height of vegetation in the front yard of each house (VEGHEIGHT), (3) the distance of the house from a natural treed area (DISTNAT), and (4) the main landscape type estimated within $50 \mathrm{~m}$ of the house (MAINLAND).
WINDOWDENS was classified as (1) dense: $>50 \%$ vegetated habitat within $2 \mathrm{~m}$ of the placed carcass, and (2) sparse: $<50 \%$ vegetated, with more pavement or human structures. YARDDENS followed the same classification as WINDOWDENS but was extended to include the entire yard the study window overlooked. VEGHEIGHT was divided into five categories: (1) no vegetation in the front yard, (2) ground-level vegetation, and vegetation that is (3) 1 storey, (4) 2 storeys, and (5) 3 storeys high. DISTNAT was divided into three categories: (1) close: house is within $100 \mathrm{~m}$ of a natural treed area, (2) mid: house is between 
100 and $250 \mathrm{~m}$ from a natural treed area, and (3) far: house is farther than $250 \mathrm{~m}$ from a natural treed area. A natural treed area was defined as recognized greenspace, using the City of Edmonton's residential and neighborhood maps and its list of city amenities. This included city parks, natural treed areas, and the North Saskatchewan River valley. MAINLAND included one of the following: (1) structures: houses and all additional buildings, (2) pavement: roads and sidewalks, (3) canopy: tree covered and forested, and (4) open vegetated habitat: lawn, grass, and field. For this classification, we used the methods and land cover types outlined in Hager et al. (2013). As outlined by Hager et al. (2013), urban bird diversity and abundance are positively correlated with vegetation and negatively correlated with urban surfaces. Thus, two broader categories were also formed for most of the area within $50 \mathrm{~m}$ of the house: (1) undeveloped: canopy and open vegetated habitat, and (2) developed:structures and pavement (LEVELDEVEL).

\section{Data analysis: covariates affecting carcass removal}

We used time-to-event (survival) analysis (Cleves et al. 2004) to plot and analyze the removal of carcasses by scavengers. Using the removal of the carcass as the event of interest in our analysis, we estimated the probability through time of carcass removal by a scavenger, and the influence of various covariates on that probability. We also carried out two additional analyses, using removals by corvids and cats separately (the two groups of scavengers that were the most common) to determine the effect of covariates on carcass removal by different groups of scavengers. We were able to detect carcass removal with complete accuracy, and our data are right-censored only at the end of our 7-day trial.

The average time to carcass removal was calculated with the restriction that right-censored trials were assumed to have failed. This method is known to underestimate the true mean survival time when no data censoring occurs. However, we choose to present the restricted mean in lieu of extrapolating the survival curve outside of our study duration, where carcass removal may become increasingly unlikely. We present estimated survival times $\pm 95 \%$ confidence intervals.

We used the Cox proportional hazards regression model, a semiparametric analysis that estimates the relative effect of covariates on the probability of an event occurring over a given time interval (the Hazard Function in STATA 13, Cleves et al. 2004). As a null model, we estimated a shared frailty for each home, the Cox regression equivalent of a random intercept model (Cleves et al. 2004), to control for nonindependence when repeatedly sampling at the same home.

We added covariates to our (1) all-scavenger, (2) corvid-scavenge, and (3) cat-scavenge models univariately and ranked each model set according to Akaike information criterion (AIC) scores (Burnham and Anderson 2004). Covariates that improved model fit by $>2 \Delta$ AIC compared to the null model were considered influential for the probability of carcass removal. We present coefficients generated by the Cox proportional hazards model as hazard ratios $\left(\exp \left[\beta_{\mathrm{i}}\right]\right)$ and standard errors. Correlation matrices generated to assess the possibility of highly correlated covariates showed no significant relationships (all $r<0.6$ ). The potential for unusually influential data points in our models was assessed using
DFBETA values, a quantification of the change in beta coefficient estimates associated with the removal of a given data point.

\section{Data analysis: carcass removal rate and bird- window collision estimate}

The carcass removal rate was calculated as the percentage of carcasses removed within the first 24 hours of trial setup. The 24hour period was used because it was the interval that citizen scientists were asked to use when searching their house for birdwindow collisions (Kummer et al. 2016a). We estimated the carcass removal rate using the method outlined in Machtans et al. (2013). The removal rate was additionally calculated for each season. We determined our seasons to be winter: October 16 to April 30, spring migration: May 1 to June 15, summer breeding: June 16 to July 31, and fall migration: August 1 to October 15.

We used our carcass removal rate to adjust the bird-window collision fatality rates reported in Kummer et al. (2016a). Kummer et al. (2016a) developed estimates of mortality based on the presence of bird feeders and whether the house was in an urban or rural setting. In calculating our estimate for Alberta, we used the mortality rate and the same parameters as our original paper but corrected for carcass removal rate, which was not done in the original study.

The Monte-Carlo simulation used by Machtans et al. (2013) was used to provide a distribution of estimates from which we produced total annual mortalities. The input parameters used by Machtans et al. (2013) for percentage of houses with feeders did not change. Input parameters are summarized in Table 2. The simulation consisted of 10,000 iterations, each with four components to simulate urban houses with and without feeders, and rural houses with and without feeders. The total number of houses in Alberta was adjusted to vary within the range of both urban/rural and feeder/no feeder proportions that we think are likely. Information on the number of houses in Alberta and the percentage of urban houses was obtained from Statistics Canada (Government of Canada 2011a, b). The same Monte-Carlo simulation was then used to estimate the number of fatalities that occurred during each season in Alberta.

Table 2. Input parameters for the Monte-Carlo simulation for calculating bird-window collision mortality at houses in Alberta.

\begin{tabular}{lc}
\hline \hline Parameter & Values \\
\hline Number of houses & $1,390,275$ \\
Percentage of urban houses & $75-85 \%$ \\
Percentage of houses with feeders & $15-25 \%$ \\
Scavenger correction & 1.471 \\
Predicted number of fatalities per house in a year & 0.48 \\
\hline
\end{tabular}

\section{RESULTS}

\section{Scavengers}

In 166 completed trials, 112 carcasses were scavenged within 7 days $(67.5 \%)$, while 54 were not. In 12 instances, although carcasses were removed, we were unable to determine time to removal due to camera failure. The average time to a carcass removal event was $3.46( \pm 0.45)$ days. The average time to carcass 
removal ranged from $2.37( \pm 0.96)$ days in spring to $4.30( \pm 0.71)$ days in winter. The time of day was not recorded correctly for a number of trials (49/166), and we were not able to detect a time of day effect in our study.

In 18 of 166 completed trials, the carcass disappeared between camera frames, and the scavenger could not be identified. The scavenger could be identified in 94 trials. The most common scavengers were Black-billed Magpies (Pica hudsonia) $(61.6 \%$ of removals; hereafter magpies) and domestic or feral cats (Felis catus) $(16.1 \%$ of removals) (Table 3 ).

Table 3. Type and sample size of scavengers reported during carcass removal trials.

\begin{tabular}{llc}
\hline \hline Scavenger & Scientific name & Sample size \\
\hline Black-billed Magpie & Pica hudsonia & 69 \\
Cat & Felis catus & 18 \\
Unknown & & 18 \\
American Crow & Corvus brachyrhynchos & 4 \\
Red Squirrel & Sciurus vulgaris & 2 \\
Blue Jay & Cyanocitta cristata & 1 \\
\hline
\end{tabular}

There were no instances of magpies visiting a site and not taking the carcass, whereas there were instances of both cats and red squirrels (Sciurus vulgaris) visiting a site but not removing the carcass. Similar to magpies, American Crows (Corvus brachyrhynchos) and Blue Jays (Cyanocitta cristata) removed the carcass whenever they visited a site. In general, cats fed on the carcass without removing it, and both times a squirrel visited a site, it removed the carcass within 2 hours of placement. However, one of these squirrels repeatedly returned to the carcass site throughout the week.

\section{Covariates affecting carcass removal}

For the all-scavenger model set, three covariates were identified as improving model fit compared to our null model (Table 4): (1) quadratic DATE $\left(\beta^{2}=0.99 \pm 0.001, \beta=1.02 \pm 0.005\right)$; $(2)$ YRBUILT, such that 1990-2009 homes were significantly less likely to have carcasses scavenged $(\beta=0.31 \pm 0.11)$ than 1940 1969 homes, while $1970-1989$ homes were intermediate $(\beta=1.06$ $\pm 0.24)$; and (3) LEVELDEVEL $(\beta=0.64 \pm 0.13)$. Similar to the all-scavenger model set, the cat-scavenge model set identified LEVELDEVEL as significantly influencing the probability of carcass removal $(\beta=0.15 \pm 0.12)$. DATE and YRBUILT were not identified as contributors to the probability of carcass removal by cats. The corvid-scavenge model set identified quadratic DATE $\left(\beta^{2}=0.99 \pm 0.001, \beta=1.02 \pm 0.007\right), \operatorname{YRBUILT}\left(\beta_{1970-1989}=0.0 .94\right.$ $\left.\pm 0.26, \beta_{1990-2009}=0.30 \pm 0.12\right)$, and WINDOWDIST $(\beta=1.004$ $\pm 0.002)$ as covariates contributing to the probability of carcass removal by corvids. Beta estimates for quadratic DATE and YRBUILT were similar between corvid-scavenge and allscavenger model sets.

The relative probability of a scavenging event changed with date, and was lowest during winter (Fig. 1). The probability of carcass removal was 7.6 times higher during mid-summer compared to mid-winter. The relative probability of carcass removal was $30 \%$ lower for houses built from 1990 to 2009 compared to 1940-1969. This probability of carcass removal was $37 \%$ lower in developed neighborhoods compared to undeveloped, while the probability of carcass removal by cats decreased by $85 \%$ in developed neighborhoods. The likelihood of removal by corvids increased by $0.4 \%$ for every $1 \mathrm{~m}$ increase in distance that the carcass was placed from the window.

Fig. 1. Effect of date on scavenger removal of bird carcasses placed below urban windows. The grey bars indicate the proportion of carcasses removed in a given month (indicated on the left y-axis), while the solid and dashed black lines indicate the relative hazards and the standard error generated by the Cox proportional hazards model, respectively (indicated on the right $y$-axis). Relative hazards are a relative rate of carcass removal over a given interval, and in July, it was $\sim 6 \mathrm{x}$ greater than in January. The number of carcasses placed in a given month is indicated below the month on the $\mathrm{x}$-axis. The data were collected near 44 Edmonton area homes, Alberta, Canada.

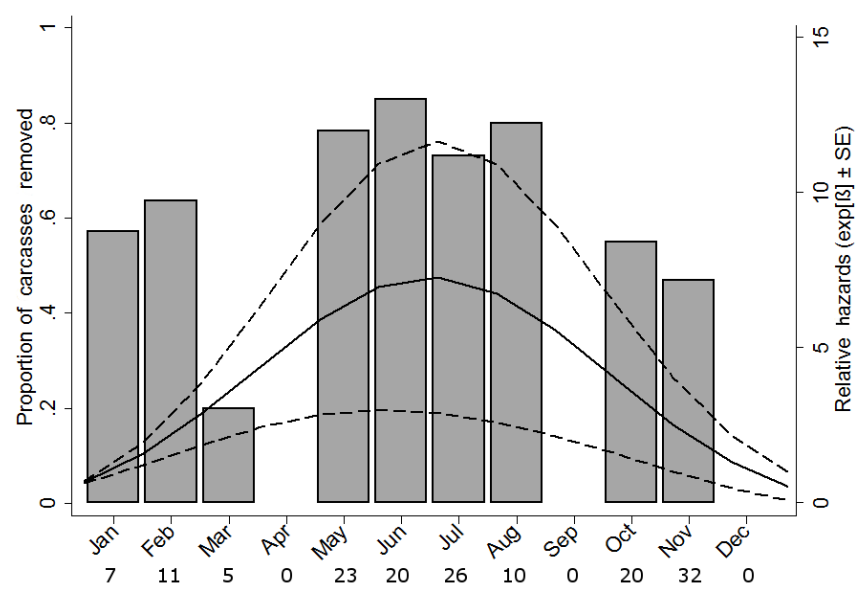

The shared frailty parameter $(\theta)$ was significant $(p<0.05)$ in all top-ranking models, which suggests that properties of individual homes can explain some of the variation that was not explained by our covariates. One home participated in five trials, and in each instance, the carcass was removed by a cat. Additionally, at three homes, magpies were responsible for four removals. Conversely, the four houses that participated in 3-4 trials did not experience a scavenging event within the experiment period.

\section{Carcass removal rate}

Carcasses were removed at a similar rate by both primary scavenging groups (Fig. 2): $48.6 \%$ and $80.0 \%$ of carcass removals by corvids occurred in the first 24 hours and 48 hours, respectively, whereas $56.3 \%$ and $75.0 \%$ of carcass removals by cats occurred in the first 24 hours and 48 hours, respectively.

Of the 154 completed trials where we know the time of removal, $31.8 \%$ of carcasses were removed in the first 24 hours. This resulted in $1 / 0.682=1.47$ carcass removal rate. The number of carcasses detected in the first 24 hours needs to be adjusted by 1.47 to account for removal by scavengers. Searcher error was not corrected for when determining our estimate because it was assumed that those homeowners who participated in the original study (Kummer et al. 2016a) completed daily searches and did not miss any collisions while they were participating. 
Table 4. Akaike information criterion (AIC) scores for each model considering the covariates that affected carcass removal by scavengers at houses. The summary also includes the relative difference between models and the best model ( $\triangle \mathrm{AIC}$ ), Akaike weights (AICw), loglikelihood (L), and number of parameters $(\mathrm{K})$. All tests were run using all scavengers, and again using removals by corvids and cats separately, the two groups of scavengers that were the most common.

\begin{tabular}{|c|c|c|c|c|c|c|c|c|c|c|c|c|c|}
\hline \multirow[t]{2}{*}{$\overline{\text { Model }^{\dagger}}$} & \multirow[t]{2}{*}{$\mathrm{K}$} & AIC & $\Delta \mathrm{AIC}$ & $\mathrm{AICW}$ & $L$ & AIC & $\Delta \mathrm{AIC}$ & $\overline{\mathrm{AICw}}$ & $L$ & AIC & $\Delta \mathrm{AIC}$ & $\mathrm{AICw}$ & $L$ \\
\hline & & \multicolumn{4}{|c|}{$\overline{A L L}$} & \multicolumn{4}{|c|}{ CAT } & \multicolumn{4}{|c|}{ CORVID } \\
\hline$\overline{\text { DATE2 }}$ & 2 & 905.53 & 0.00 & 0.84 & -450.76 & 141.44 & 5.27 & 0.03 & -68.72 & 624.73 & 0.00 & 1.00 & -310.4 \\
\hline YRBUILT & 2 & 908.93 & 3.41 & 0.15 & -452.47 & 138.57 & 2.39 & 0.12 & -67.28 & 639.88 & 15.14 & 0.00 & -317.9 \\
\hline LEVELDEVEL & 1 & 919.54 & 14.02 & 0.00 & -458.77 & 136.17 & 0.00 & 0.39 & -67.09 & 649.25 & 24.52 & 0.00 & -323.6 \\
\hline WINDOWDIST & 1 & 920.31 & 14.79 & 0.00 & -459.16 & 141.49 & 5.31 & 0.03 & -69.74 & 645.47 & 20.74 & 0.00 & -321.7 \\
\hline WINDOWDIST2 & 2 & 921.85 & 16.33 & 0.00 & -458.93 & 141.43 & 5.26 & 0.03 & -68.72 & 647.46 & 22.73 & 0.00 & -321.7 \\
\hline NULL & 0 & 921.90 & 16.38 & 0.00 & -460.95 & 140.23 & 4.05 & 0.05 & -70.11 & 647.94 & 23.21 & 0.00 & -324.0 \\
\hline MAINLAND & 3 & 922.11 & 16.58 & 0.00 & -460.44 & 139.38 & 3.20 & 0.08 & -66.69 & 651.38 & 26.65 & 0.00 & -322.7 \\
\hline DISTNAT & 2 & 922.34 & 16.82 & 0.00 & -459.17 & 138.19 & 2.02 & 0.14 & -67.09 & 651.76 & 27.02 & 0.00 & -323.9 \\
\hline DATE & 1 & 923.00 & 17.48 & 0.00 & -460.50 & 142.17 & 5.99 & 0.02 & -70.08 & 647.35 & 22.62 & 0.00 & -322.7 \\
\hline WINDOWDENS & 1 & 923.50 & 17.98 & 0.00 & -460.85 & 139.42 & 3.24 & 0.08 & -68.71 & 649.94 & 25.21 & 0.00 & -323.0 \\
\hline VEGHEIGHT & 3 & 925.18 & 19.66 & 0.00 & -459.59 & 142.15 & 5.98 & 0.02 & -68.07 & 652.97 & 28.24 & 0.00 & -323.5 \\
\hline $\begin{array}{l}\text { WINDOWDIR- } \\
\text { ECT }\end{array}$ & 3 & 926.77 & 21.25 & 0.00 & -460.39 & 143.35 & 7.18 & 0.01 & -68.67 & 651.67 & 26.94 & 0.00 & -322.8 \\
\hline
\end{tabular}

DATE: date the carcass was placed below the window; YRBUILT: year the house was built; LEVELDEVEL: developed—structures and pavement; WINDOWDIST: distance the bird carcass was placed from the window; MAINLAND: main landscape type estimated within $50 \mathrm{~m}$ of the house; DISTNAT: distance of the house from a natural treed area; WINDOWDENS: density of vegetation in the $2 \mathrm{~m}$ area surrounding the placed carcass (dense or sparse); VEGHEIGHT: average height of vegetation in the front yard of each house; WINDOWDIRECT: direction the study window faced

Fig. 2. Kaplan-Meier Failure curves showing the proportional removal of 154 bird carcasses by scavengers through time (placement of the carcass $=0$ ). The "All scavengers" curve plots the carcass removal by any scavenger, while the "Cat" and "Corvid" curves plot carcass removal by the two most common scavenger types. This experiment was documented using timelapse cameras at 44 homes near Edmonton, Alberta, Canada.

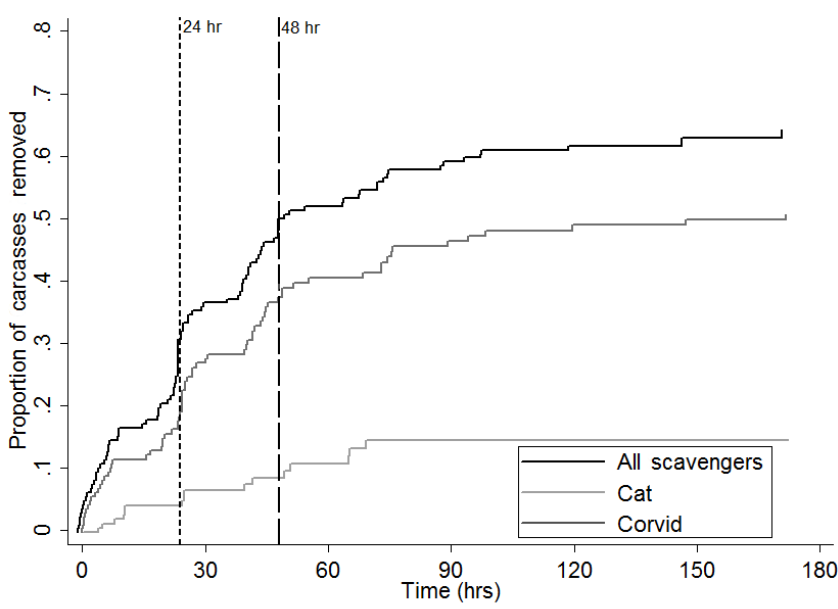

In the first 24 hours, the highest carcass removal rate occurred during spring $(50.0 \%$ removed). The next highest occurred during summer $(42.5 \%)$, followed by winter $(15.8 \%)$ and fall $(15.0 \%)$. This resulted in a carcass removal rate of 2.00 during spring, followed by 1.74 during summer, 1.19 during winter, and 1.18 during fall.

\section{Bird-window collision estimate}

The estimated average number of birds killed at houses in Alberta each year was 651,432 ( \pm 39,383 SD; range: 532,396-770,030) when there was no adjustment for carcass removal.

Using our carcass removal rate, the estimated average annual number of birds killed at houses in Alberta was 957,440 $( \pm 59,280$ SD). The simulation produced an upper bound of $1,137,775$ and lower bound of 791,438. Urban houses without a feeder are the most abundant in Alberta and accounted for the largest percentage of fatalities $(42 \%)$. Urban houses with a feeder accounted for $16 \%$ of fatalities. The equivalent figures for rural houses with and without a bird feeder were $12 \%$ and $30 \%$, respectively.

The largest number of fatalities was estimated to occur during summer ( 527,852 fatalities), followed closely by fall migration (504,779 fatalities). There were fewer collisions during spring migration (352,249 fatalities) and a considerably lower number during winter $(55,670$ fatalities). Estimating the number of fatalities by season resulted in a total of 1,440,551 ( \pm 93,211 SD) birds killed annually in Alberta. Adjusting for a seasonal correction factor resulted in an upper bound of 1,701,187 and a lower bound of $1,182,166$.

\section{DISCUSSION}

\section{Covariates affecting carcass removal}

The factors affecting carcass survival time are similar to those factors we identified as having a large effect on bird-window collisions (Kummer et al. 2016b). This suggests that those homes that are experiencing a large number of collisions are probably experiencing a higher number of scavenging events that need to be corrected for when estimating collision rates. 
There was a greater proportion of carcasses removed during spring and summer than during winter and fall, yet this difference between seasons was smaller than in other studies. For example, in Hager et al.'s (2012) study, only two carcasses were removed during winter, a number far lower than that recorded during any other season (e.g., 13 removed during fall). The greatest difference between our study and Hager et al.'s (2012) is that their study recorded the largest number of carcasses removed in the fall $(65 \%)$, whereas during our fall period, there were fewer removals relative to other seasons. There was a larger year-round scavenger presence in our study area than in Hager et al.'s (2012) study area. Magpies were responsible for the largest number of carcass removals, especially those carcasses that were removed during winter. Magpies are opportunistic omnivores and are abundant year-round in the Edmonton area, where they are brought closer to human-affected areas during winter. In contrast, Hager et al. (2012) found raccoons to be the most prominent scavenger in Illinois, and they are known to be less active in cold climates during winter. Homeowners did not collect information on the overall bird abundance or scavenger composition in Edmonton, but this would be a useful component of future studies.

The age of the house and the level of development within $50 \mathrm{~m}$ of the house were covariates that affected carcass removal; in our previous studies (Kummer et al. 2016a,b), they also had an effect on collision risk. Both of these covariates are likely related to the abundance and composition of vegetation in a yard. Yards with more vegetation were associated with a larger number of collisions, likely as a result of more birds being drawn to the area for foraging and nesting. Carcass removal rates were higher in those yards; therefore, it is possible that more scavengers are being drawn to these yards or spending more time there, perhaps because more vegetation increases food availability, provides greater concealment for scavengers or predators, and provides more perches for avian scavengers.

Bird feeders have been identified as one of the largest factors affecting bird-window collisions at houses (Kummer and Bayne 2015, Kummer et al. 2016b), yet bird feeder presence was not included as a variable in this study. One potential bias of our study may be that participants were especially likely to be interested in birds. This could result in, for example, an increased likelihood of bird feeders or houses occurring in the yards of study participants compared to the provincial rate. However, Kummer et al. (2016a) found voluntary participants maintained bird feeders in a similar proportion to the Alberta average. Regardless, it is unclear how enthusiastic birder activities might affect birdwindow collisions or scavenger removal of carcasses, and this may be an important area of research to minimize negative effects on birds. Homeowners are concerned that bird feeder presence might lead to an increased risk of predation, but previous research has shown this is not likely the case (Dunn and Tessaglia 1994, Robb et al. 2008). Instead, those birds that frequent feeders have shown increased vigilance and occur in smaller numbers at a feeder. For similar reasons, and as a result of more homeowners keeping their cats indoors, the presence of a feeder has been linked to lower levels of bird predation by cats (Woods et al. 2003, Robb et al. 2008).

Through the course of the study, six houses never experienced a scavenging event, despite having up to four trials conducted in their yard. On the other hand, there were two houses that experienced four carcass removals by magpies, and another where a cat removed carcasses in all five trials. As a result, this house was highly influential for the factors affecting carcass removal by cats. There were no identifiable differences between these houses. This suggests that there are other factors we did not account for that had an effect on carcass removal. At those houses with multiple removals, bird-window collisions may have implications on scavenger behavior as well, especially on learned behavior, where scavengers revisit buildings with a high number of birdwindow collisions because they provide a predictable source of food (Klem 1981, Hager et al. 2012).

\section{Scavenger removal across studies}

Our study, Hager et al. (2012), and Bracey et al. (2016) each completed scavenger removal studies at houses. The results of these studies are comparable. However, owing to different statistical methods, the results cannot be directly compared. For example, Hager et al. (2012) and Bracey et al. (2016) each reported the expected survival time of a carcass, yet this was not calculated the same way between the studies, whereas we reported the average survival time. There are biases associated with each method of estimating survival time, and future studies will benefit from consistent result reporting so that different survival times across studies are informative rather than methodological. We recommend the use of restricted mean survival time, as we have reported our results, for future studies, despite the potential to underestimate true survival time. This method does not require the extrapolation of the survival curve beyond the duration of the study because it assumes that trials where the carcass remained failed. Additionally, future studies should attempt to better record time of placement and time of carcass removal to better identify differences in removal during the first 24 hours after placement.

Our average survival time of 3.46 days was similar to the estimated survival time of 4.33 days reported by Bracey et al. (2016) during bird migratory periods. Hager et al. (2012) split their results between winter and the other seasons. The low end of Hager et al.'s (2012) prediction for the nonwinter seasons is similar to our average survival time. However, compared to Hager et al. (2012), we did not find a large difference in the average time to a removal event between seasons. Two carcass removal studies have been conducted on university campuses in the eastern United States (Klem et al. 2004, Horn and Collins 2006). Our results are comparable to the 2.4-2.6 average days until removal reported by Horn and Collins (2006), but in Klem et al.'s (2004) study, only $12.8 \%$ of carcasses were found and disturbed, and no other results were reported for comparison.

Similar to urban studies, there was a wide range of survival times at various wind turbine studies. For example, Erickson et al. (2000) reported an average survival time of 25.0 days in Oregon, whereas Smallwood et al. (2010) reported 4.45 days in California. Villegas-Patraca et al. (2012) reported similar results in Mexico to those of Smallwood et al. (2010). Each of these studies had larger average survival times than our study, which suggests that the results from wind turbine studies are not accurate for use in estimates of urban bird-window collision fatalities. One scavenger study associated with power lines reported that only $32 \%$ of carcasses were removed after 48 hours (Ponce et al. 2010), which was quite a bit lower than our $50.6 \%$. 
Avian Conservation and Ecology 11(2): 12 http://www.ace-eco.org/vol11/iss2/art12/

We reported a 1.47 carcass removal rate for daily carcass searches. No other study has reported results in this way, except for Machtans et al. (2013), whose study we replicated. Our carcass removal rate was lower than the 2.3-5.0 birds missed in Machtans et al.'s (2013) study. Their numbers on the lower end were based on wind turbine studies; fewer birds were missed during our urban trials.

Our 1.47 carcass removal rate was determined by using windows on only the front of a house. While we chose to exclude potential variation between front yard- and backyard-facing windows in our study, there may be significant differences in carcass removal between sides of the house, which would result in a different correction factor for windows that face the backyard.

Throughout Kummer et al.'s (2016a, $b$ ) studies, homeowners were asked to complete daily searches for evidence of a bird-window collision. However, with only $31.8 \%$ of carcasses in Edmonton removed in 24 hours, daily searches may not be needed. The average time to removal was 3.46 days. Instead, completing carcass searches every 2-3 days may be acceptable with the application of appropriate corrections.

\section{Alberta bird-window collision estimate}

Our estimated 957,440 fatalities at houses in Alberta is the most detailed estimate of bird-window collision mortality in Canada. We have improved upon past Canadian bird-window collision estimates (Machtans et al. 2013, Kummer et al. 2016a, b) by conducting a complimentary carcass removal study in the same area, at many of the same houses. Fourteen percent of all houses in Canada are located in Alberta (Government of Canada 2011b). However, in comparing the estimates from our study and those from Machtans et al. (2013), our 957,440 fatalities represent only $4 \%$ of the previously estimated 22.4 million collision fatalities at houses (Machtans et al. 2013). One main reason for this difference is that our removal rate was smaller than that used in the original Canadian estimate. The fewer numbers of birds missed drastically reduced the reported number of collisions and resulted in less variation between houses. The estimated number of fatalities doubled to 2,384,234 ( $\pm 329,999 \mathrm{SD})$ when we used the 2.3-5 birds missed for every bird found as reported by Machtans et al. (2013). Additionally, the predicted number of fatalities reported in Kummer et al. (2016a) was less than the original Bayne et al. (2012) study that the first Canadian estimate was based on.

These estimates are based on the most detailed bird-window collision study at houses to date and a carcass removal study located in the same area. We have attempted to increase the accuracy of calculating the number of bird-window collision fatalities in Alberta, an area from which the collected data were obtained. Unlike previous studies, we did not attempt to extrapolate our results to other areas across Canada. If we are to improve the current bird-window collision mortality estimate for Canada, more localized studies like ours need to be conducted. Completing studies at a provincial level will help reduce a number of the existing biases in the fatality estimate at houses.

Responses to this article can be read online at: http://www.ace-eco.org/issues/responses.php/927

\section{Acknowledgments:}

We want to thank the 44 families who allowed us to place a dead bird in the front yard of their home multiple times during the course of the study. Their continued interest in and dedication to the project was greatly appreciated. This project would not have been a success without them. The Department of Biological Sciences at the University of Alberta and Environment Canada provided funding for the project. This research was conducted under permits \#Pro000413111 and \#AUP00001361 from the Research Ethics Board at the University of Alberta and Canadian Wildlife Service permit 14-AB-SC008.

\section{LITERATURE CITED}

Balcomb, R. 1986. Songbird carcasses disappear rapidly from agricultural fields. Auk 103(4):817-820.

Bayne, E. M., C. A. Scobie, and M. Rawson-Clark. 2012. Factors influencing the annual risk of bird-window collisions at residential structures in Alberta, Canada. Wildlife Research 39:583-592. http://dx.doi.org/10.1071/WR11179

Bispo, R., J. Bernardino, T. A. Marques, and D. Pestana. 2013. Modeling carcass removal time for avian mortality assessment in wind farms using survival analysis. Environmental and Ecological Statistics 20:147-165. http://dx.doi.org/10.1007/s10651-012-0212-5

Bracey, A. M., M. A. Etterson, G. J. Niemi, and R. F. Green. 2016. Variation in bird-window collision mortality and scavenging rates within an urban landscape. Wilson Journal of Ornithology 128(2):355-367. http://dx.doi.org/10.1676/ wils-128-02-355-367.1

Burnham, K. P., and D. R. Anderson. 2004. Multimodel inference - understanding AIC and BIC in model selection. Sociological Methods \& Research 33:261-304. http://dx.doi. org/10.1177/0049124104268644

Calvert, A. M., C. A. Bishop, R. D. Elliot, E. A. Krebs, T. M. Kydd, C. S. Machtans, and G. J. Robertson. 2013. A synthesis of human-related avian mortality in Canada. Avian Conservation and Ecology 8(2):11. http://dx.doi.org/10.5751/ACE-00581-080211

Cleves, M., W. W. Gould, and R. G. Gutierrez. 2004. An introduction to survival analysis using STATA. Stata Press, College Station, Texas, USA.

Dunn, E. H. 1993. Bird mortality from striking residential windows in winter. Journal of Field Ornithology 64:302-309.

Dunn, E. H., and D. L. Tessaglia. 1994. Predation of birds at feeders in winter. Journal of Field Ornithology 65(1):8-16.

Erickson, W. P., G. D. Johnson, M. D. Strickland, and K. Kronner. 2000. Final report: avian and bat mortality associated with the vansycle wind project, Umatilla County, Oregon. 1999 study year. Umatilla County Department of Resource Services and Development, Pendleton, Oregon, USA.

Government of Canada. 2011a. From urban areas to population centres. Statistics Canada. http://www.statcan.gc.ca/eng/subjects/ standard/sgc/notice/sgc-06 
Government of Canada. 2011b. Private households by structural type of dwelling, by province and territory (2011 census). Statistics Canada. http://www.statcan.gc.ca/tables-tableaux/sum-som/101/ cst01/famil55c-eng.htm

Hager, S. B., B. J. Cosentino, and K. J. McKay. 2012. Scavenging affects persistence of avian carcasses resulting from window collisions in an urban landscape. Journal of Field Ornithology 83:203-211. http://dx.doi.org/10.1111/j.1557-9263.2012.00370.x

Hager, S. B., B. J. Cosentino, K. J. McKay, C. Monson, W. Zuurdeeg, and B. Blevins. 2013. Window area and development drive spatial variation in bird-window collisions in an urban landscape. PLoS ONE 8(1).

Horn, D. J., and K. A. Collins. 2006. Bird-window collisions and factors influencing their frequency at Millikin University in Decatur, Illinois [Poster].

Klem, D. 1981. Avian predators hunting birds near windows. Proceedings of the Pennsylvania Academy of Science 55:90-92.

Klem, D., D. C. Keck, K. L. Marty, A. J. Miller Ball, E. E. Niciu, and C. T. Platt. 2004. Effects of window angling, feeder placement, and scavengers on avian mortality at plate glass. Wilson Bulletin 116:69-73. http://dx.doi.org/10.1676/0043-5643 (2004)116[0069:EOWAFP]2.0.CO;2

Kostecke, R. M., G. M. Linz, and W. J. Bleier. 2001. Survival of avian carcasses and photographic evidence of predators and scavengers. Journal of Field Ornithology 72(3):439-447. http://dx. doi.org/10.1648/0273-8570-72.3.439

Kummer, J. A., and E. M. Bayne. 2015. Bird feeders and their effect on bird-window collisions at residential houses. Avian Conservation and Ecology 10(2):6.

Kummer, J. A., E. M. Bayne, and C. S. Machtans. $2016 a$. Comparing the results of recall surveys and standardized searches in understanding bird-window collisions at houses. Avian Conservation and Ecology 11(1):4. http://dx.doi.org/10.5751/ ACE-00820-110104

Kummer, J. A., E. M. Bayne, and C. S. Machtans. 2016b. Use of citizen science to identify factors affecting bird-window collision risk at houses. Condor: Ornithological Applications 118:624-639.

Loss, S. R., T. Wil, S. S. Loss, and P. P. Marra. 2014. Bird-building collisions in the United States: estimates of annual mortality and species vulnerability. Condor 116:8-23. http://dx.doi.org/10.1650/ condor-13-090.1

Machtans, C. S., C. H. R. Wedeles, and E. M. Bayne. 2013. A first estimate for Canada of the number of birds killed by colliding with building windows. Avian Conservation and Ecology 8(2):6. http://dx.doi.org/10.5751/ACE-00568-080206

Pain, D. J. 1991. Why are lead-poisoned waterfowl rarely seen?: the disappearance of waterfowl carcasses in the Camargue, France. Wildfowl 42:118-122.

Ponce, C., J. C. Alonso, G. Argandoña, A. G. Fernández, and M. Carrasco. 2010. Carcass removal by scavengers and search accuracy affect bird mortality estimates at power lines. Animal Conservation 13:603-612. http://dx.doi.org/10.1111/

j.1469-1795.2010.00387.x
Prosser, P., C. Nattrass, and C. Prosser. 2008. Rate of removal of bird carcasses in arable farmland by predators and scavengers. Ecotoxicology and Environmental Safety 71:601-608. http://dx. doi.org/10.1016/j.ecoenv.2007.10.013

Ragg, J. R., C. G. Mackintosh, and H. Moller. 2000. The scavenging behaviour of ferrets (Mustela furo), feral cats (Felis domesticus), possums (Trichosurus vulpecula), hedgehogs (Erinaceus europaeus) and harrier hawks (Circus approximans) on pastoral farmland in New Zealand: implications for bovine tuberculosis transmission. New Zealand Veterinary Journal 48:166-175. http://dx.doi.org/10.1080/00480169.2000.36188

Robb, G. N., R. A. McDonald, D. E. Chamberlain, and S. Bearhop. 2008. Food for thought: supplementary feeding as a driver of ecological change in avian populations. Frontiers in Ecology and the Environment 6(9)476-484. http://dx.doi. org/10.1890/060152

Rosene, W., and D. W. Lay. 1963. Disappearance and visibility of quail remains. Journal of Wildlife Management 27(1):139-142. http://dx.doi.org/10.2307/3797792

Smallwood, K. S. 2007. Estimating wind turbine-caused bird mortality. Journal of Wildlife Management 71:2781-2791. http:// dx.doi.org/10.2193/2007-006

Smallwood, K. S. 2013. Comparing bird and bat fatality-rate estimates among North American wind-energy projects. Wildlife Society Bulletin 37(1):19-33. http://dx.doi.org/10.1002/wsb.260

Smallwood, K. S., D. A. Bell, S. A. Snyder, and J. E. DiDonato. 2010. Novel scavenger removal trials increase wind turbinecaused avian fatality estimates. Journal of Wildlife Management 74(5):1089-1097. http://dx.doi.org/10.2193/2009-266

Stevens, B. S., K. P. Reese, and J. W. Connelly. 2011. Survival and detectability bias of avian fence collision surveys in sagebrush steppe. Journal of Wildlife Management 75(2):437-449. http://dx. doi.org/10.1002/jwmg.53

STATA 13. StataCorp, College Station, Texas, USA. [software] URL: http://www.stata.com

Tobin, M. E., and R. A. Dolbeer. 1990. Disappearance and recoverability of songbird carcasses in fruit orchards. Journal of Field Ornithology 61(2):237-242.

Villegas-Patraca, R., S. Macias-Sánchez, I. MacGregor-Fors, and C. Muñoz-Robles. 2012. Scavenger removal: bird and bat carcass persistence in a tropical wind farm. Acta Oecologica 43:121-125. http://dx.doi.org/10.1016/j.actao.2012.06.004

Ward, M. R., D. E. Stallknecht, J. Willis, M. J. Conroy, and W. R. Davidson. 2006. Wild bird mortality and West Nile virus surveillance: biases associated with detection, reporting, and carcass persistence. Journal of Wildlife Diseases 42(1):92-106. http://dx.doi.org/10.7589/0090-3558-42.1.92

Wobeser, G., and A. G. Wobeser. 1992. Carcass disappearance and estimation of mortality in a simulated die-off of small birds. Journal of Wildlife Diseases 28(4):548-554. http://dx.doi. org/10.7589/0090-3558-28.4.548 
Woods, M., R. A. McDonald, and S. Harris. 2003. Predation of wildlife by domestic cats Felis catus in Great Britain. Mammal Review 33(2)174-188. http://dx.doi.org/10.1046/j.1365-2907.2003.00017.

$\mathrm{x}$

Woronecki, P. P., R. A. Dolbeer, C. R. Ingram, and A. R. Stickley. 1979. 4-aminopyridine effectiveness reevaluated for reducing blackbird damage to corn. Journal of Wildlife Management 43 (1):184-191. http://dx.doi.org/10.2307/3800650

Zimmerling, J. R., A. C. Pomeroy, M. V. d'Entremont, and C. M. Francis. 2013. Canadian estimate of bird mortality due to collisions and direct habitat loss associated with wind turbine developments. Avian Conservation and Ecology 8(2):10. http://dx. doi.org/10.5751/ace-00609-080210 